\title{
BRPKM
}

Buletin Riset Psikologi dan Kesehatan Mental

http://e-journal.unair.ac.id/index.php/BRPKM

e-ISSN: 2776-1851

ARTIKEL PENELITIAN

\section{Pengaruh Grit terhadap Self-Determination pada Atlet yang Memutuskan Kembali Pasca Cedera Berat}

\author{
AZZAH AMBARANI HIDAYAT \& AFIF KURNIAWAN* \\ Fakultas Psikologi Universitas Airlangga
}

\begin{abstract}
ABSTRAK
Penelitian ini bertujuan untuk menguji apakah terdapat pengaruh grit terhadap self-determination pada atlet yang memutuskan kembali pasca mengalami cedera berat. Self-Determination Theory memaparkan perkembangan kebutuhan dasar psikologis individu yang sifatnya melekat (inherent) dan dibawa sejak lahir (innate) sebagai faktor motivasi pada perilaku individu. Sedangkan grit mengukur ketertarikan seseorang apakah ia mampu fokus dan bertahan terhadap suatu bidang atau sering berganti-ganti ketertarikan pada suatu bidang tertentu. Partisipan dalam penelitian ini merupakan atlet yang memutuskan kembali pasca cedera berat. Metode yang digunakan dalam penelitian ini merupakan kuantitatif eksplanatori. Pengambilan data diambil menggunakan survei google form dan mendapatkan 72 responden. Hasil dari penelitian ini menunjukan bahwa terdapat pengaruh yang signifikan pada grit terhadap self-determination atlet yang memutuskan kembali pasca cedera berat.
\end{abstract}

Kata kunci: atlet, grit, self-determination

\begin{abstract}
This study aims to examine whether there is an effect of grit on self-determination in athletes who decide to return after experiencing a serious injury. Self-Determination Theory describes the development of individual psychological basic needs that are inherent and innate as motivational factors for individual behavior. While Grit measures a person's interest in whether he is able to focus and persist in a field or frequently alternate interests in a particular field. The subjects in this study were athletes who decided to return after a serious injury. The method used in this research is explanatory quantitative. Data collection was taken using a google form survey and got 72 respondents. The results of this study indicate that there is a significant effect on grit on self-determination athletes who decide to return after a serious injury.
\end{abstract}

Keywords: atlet, grit, self-determination

Buletin Penelitian Psikologi dan Kesehatan Mental (BRPKM), 2021, Vol. 1(2), 1172-1179

*Alamat korespondensi: Fakultas Psikologi Universitas Airlangga, Kampus B Universitas Airlangga Jalan Airlangga 4-6 Surabaya 60286. Surel: afif.kurniawan@psikologi.unair.ac.id

Naskah ini merupakan naskah dengan akses terbuka dibawah ketentuan the Creative Common Attribution License (CC-BY-4.0) (http://creativecommons.org/licenses/by/4.0), sehingga penggunaan, distribusi, reproduksi dalam media apapun atas artikel ini tidak dibatasi, selama sumber aslinya disitir dengan baik. 


\section{PEN D A H U L U A N}

Para peneliti yang berfokus pada aspek psikososial cedera olahraga sebagian besar telah memeriksa variabel penyebab dari cedera dan faktor-faktor yang mempengaruhi rehabilitasi dan pemulihan (Lavallee dkk., 2020). Baru-baru ini, peneliti juga mulai memeriksa faktor psikologis yang terkait dengan kembalinya atlet ke olahraga setelah cedera (Podlog \& Eklund, 2010). Banyaknya kompetisi olahraga yang diadakan setiap tahunnya, menuntut para atlet untuk terus berlatih dan berprestasi. Banyak tantangan dan risiko yang harus dihadapi oleh atlet demi menggapai juara. Seorang atlet membutuhkan ketekunan dalam melakukan rutinitas latihannya dengan intensitas tinggi dan disertai dengan tekanan dalam berkompetisi, operasional organisasi, dan juga kegiatan pribadi selain olahraga (Santi dkk., 2013).

Penelitian yang dilakukan oleh Santi \& Pietrantoni (2013) mengatakan bahwa seorang atlet profesional menghabiskan waktu selama ribuan jam untuk belatih, dengan risiko cedera yang lebih tinggi daripada olahragawan normal sedangkan atlet non-profesional berdasarkan Kamus Besar Bahasa Indonesia adalah kegiatan yang dilakukan atas dasar kesenangan dan bukan untuk memperoleh nafkah. Survei yang dilakukan di Amerika Serikat oleh National Collegiate Athletic Assosiation (NCAA) Divisi I menyatakan bahwa sebanyak 70\% atlet pernah mengalami cedera, serta lebih dari setengahnya merasa tertekan ketika bermain dalam kondisi cedera (O'Connell \& Manschreck, 2012). Masing-masing cabang olahraga memiliki probabilitas cedera yang berbeda, misalnya pada cabang olahraga selancar angin terdapat 13 kasus cedera setiap 1000 jam latihan, sedangkan pada cabang olahraga sepak bola terdapat $75 \%$ pemain profesional yang mengalami cedera setiap musimnya. Terdapat juga perbedaan probalitas terjadinya kasus cedera berdasarkan gender di Amerika Serikat, umumnya kasus pada pria lebih banyak daripada wanita (Santi dkk., 2013).

Cedera pada atlet seringkali menimbulkan konsekuensi negatif, baik secara fisik maupun psikologis. Respon emosional yang muncul ketika atlet mengalami cedera antara lain, kesedihan, isolasi diri, rasa kesal, penurunan motivasi, kemarahan, frustasi, perubahan nafsu makan, gangguan tidur, dan penolakan (Brown dkk., 2014). Dampak tersebut bergantung pada beberapa faktor, yaitu investasi waktu pada olahraga tersebut, kuat atau tidaknya olahraga tersebut sebagai identitasnya, perasaan kehilangan, gangguan mood, serta banyaknya sumber daya psikologis individu dalam menghadapi situasi tersebut (Santi \& Pietrantoni, 2013).

Cedera bisa menjadi alasan utama atlet menghentikan kariernya (Ristolainen dkk., 2012). Para atlet yang memiliki risiko lebih tinggi untuk mengakhiri kariernya merupakan atlet yang lebih tua dengan cedera yang spesifik pada cabang olahraga tertentu. Misalnya pada sepak bola dengan cedera lututnya, membuktikan bahwa 78\% dari pemainnya memilih untuk berhenti dari sepak bola setelah mengalami cedera ACL. Penelitian yang dilakukan oleh Ristolainen dkk. (2012) menyatakan bahwa 70\% atlet yang mengakhiri karirnya melaporkan bahwa cedera menyebabkan mereka mengalami cacat permanen, ringan, atau sedang.

Menurut penelitian Johnston \& Carroll (1998) mengungkapkan sejumlah kesulitan psikologis pada kembalinya atlet awal partisipasi olahraga. Secara khusus, beberapa atlet percaya kepercayaan diri mereka lebih rendah daripada sebelum cedera. Ketakutan akan cedera kembali atau cedera pada bagian tubuh lain juga menonjol bagi para atlet ini. Ketakutan akan cedera terwujud dalam beberapa cara: raguragu, menahan diri, tidak memberikan upaya dan tenaga 100\%, berhati-hati terhadap situasi yang memicu cedera (terutama situasi yang mirip dengan konteks kejadian cedera mereka), dan ingatan yang kuat tentang luka bagian tubuh. Bagi mereka yang memiliki riwayat cedera pada bagian tubuh tertentu, ketakutan akan cedera kembali meningkat karena kesadaran akan kelemahan ini. Beberapa kasus atlet dengan cedera yang mampu kembali berlatih bahkan berprestasi sama atau lebih baik dari sebelumnya 
(Hasanah, 2019). Kasus lainnya menunjukkan bahwa cedera juga bisa mengakibatkan atlet menghentikan kariernya (Foss dkk., 2018).

Magee dkk. (2010) mengatakan bahwa dalam menyikapi cedera, atlet menyikapinya dengan back to sport, back to performance, atau retire. Back to Sport merupakan atlet yang kembali ke olahraga, tetapi tidak pada tingkat kinerja targetnya. Back to Performance adalah atlet telah kembali ke olahraganya dan tampil pada atau lebih baik dari level sebelum cedera. Gledhill \& Forsdyke (2021) menjelaskan bagaimana risiko dalam berolahraga, respon terhadap risiko, rehabilitasi, kembali dalam berolahraga, hingga retirement. Disebutkan apabila atlet mengalami cedera yang cukup serius hingga tidak bisa kembali dalam berolahraga maka kebanyakan atlet akan memilih untuk retire atau mengundurkan diri dari dunia olahraga.

Menjadi atlet dapat mengorbankan tubuh mereka untuk dianggap sebagai atlet kompetitif "sejati". Berbagai jenis motivasi yang mendorong kembalinya atlet ke olahraga setelah cedera dapat mempengaruhi penilaian dan emosi mengenai pengembalian tersebut. Self-determination sendiri merupakan faktor penting untuk tentang kembalinya dari cedera atlet (Hughes \& Coakley, 2016). Penelitian sebelumnya menunjukkan bahwa berbagai motivasi dapat memberi energi pada atlet untuk kembali berolahraga setelah cedera. Atlet mungkin berusaha untuk kembali mengalami kesenangan intrinsik dan rasa kepuasan yang terkait dengan bersaing dalam olahraga mereka (Podlog \& Eklund, 2010). Atlet juga dapat dibujuk untuk kembali melalui insentif moneter atau ancaman sanksi paksaan (Bianco \& Eklund, 2001). Selain itu, beberapa atlet yang cedera mungkin termotivasi untuk kembali ke olahraga untuk menegaskan kembali identitas mereka sebagai atlet (Van Raalte dkk., 1993).

Podlog \& Eklund (2007) menunjukkan bahwa atlet yang kembali biasanya mengalami kekhawatiran atau kesulitan dalam tiga bidang psikologis: competency, autonomy, and relatedness. Mengingat fokus pada tiga area di self-determination ini mungkin merupakan kerangka yang sangat berguna untuk menafsirkan dan memahami pengalaman atlet dalam kembali ke olahraga setelah cedera. Ryan dan Deci Deci \& Ryan (2012) mengusulkan bahwa sejauh mana kebutuhan ini terpenuhi memberikan gambaran tentang keadaan motivasi individu. Keadaan motivasi ini berkisar dari tidak termotivasi hingga termotivasi secara intrinsik. Bianco dan Gould (2001 dalam Podlog \& Eklund, 2007) penelitian mereka menunjukkan bahwa tingkat otonomi atlet dalam kembali ke olahraga setelah cedera (yaitu, motivasi mereka untuk kembali) dapat mempengaruhi hasil saat mereka kembali ke olahraga (misalnya, tingkat kecemasan, kepercayaan diri, dan persepsi terhadap performa). Hal tersebut memungkinkan atlet dapat memaksimalkan keterampilannya setelah kembali (Williams, \& Roepke, 1993). Penelitian lain tentang bagaimana atlet kembali pasca cedera dilakukan oleh Podlog \& Eklund (2010) dengan hasil penelitiannya menunjukan bahwa atlet dengan self-determination akan mempengaruhi bagaimana atlet tersebut kembali berkompetisi serta memberikan gambaran emosi yang lebih baik saat berpikir tentang cedera yang mungkin akan mereka alami lagi di masa depan. Scharneck (2017) menyatakan bahwa terdapat hubungan yang positif antara grit dan mental toughness terhadap self-determination pada siswa yang menjadi atlet. Pemeriksaan grit dan mental toughness terhadap self-determination mendukung pandangan holistik tentang motivasi yang dapat mendorong performa dan psychological well-being atlet.

Kesuksesan seseorang tidak hanya karena dia berbakat, ada faktor lain yang menyebabkan seseorang mampu bertahan pada satu tujuan selama bertahun-tahun hingga akhirnya meraih kesuksesan (Duckworth, 2016). Faktor prediktor tersebut adalah grit, semakin tinggi nilai grit maka peluang untuk sukses akan semakin besar, hal tersebut berlaku dalam berbagai aspek kehidupan. Duckworth dkk. (2007) mengemukakan bahwa grit memiliki dua dimensi yaitu consistensy of interest dan perverence of effort. Dimana consistensy of interest menunjukkan adanya kemampuan mempertahankan minat atau 
ketertarikan pada suatu tujuan jangka panjang dan perverence of effort menunjukan adanya ketekunan dalam berusaha pada suatu tujuan jangka panjang. Grit diartikan juga sebagai ketekunan dalam berusaha dan konsistensi minat seseorang untuk meraih tujuan jangka panjang yang berkaitan dengan kesuksesan dalam berbagai bidang (Duckworth dkk., 2007). Sebagai prediktor kesukesan, grit didukung oleh kontrol diri yang membuat seseorang mampu bertahan dalam perilaku-perilaku berulang, membosankan, ataupun membuat frustrasi (Duckworth \& Gross, 2014). Belum banyak penelitian yang meneliti tentang bagimana grit dapat berpengaruh pada self-determination terutama dalam konteks kembalinya atlet pasca cedera berat. Sehingga peneliti tertarik untuk mengetahui pengaruh grit terhadap self-determination atlet yang memilih kembali pasca cedera berat untuk mengetahui apakah variabel grit dapat mempengaruhi self-determination.

\section{MET O D E}

\section{Desain Penelitian}

Pendekatan yang digunakan dalam penelitian ini menggunakan pendekatan kuantitatif. Penelitian ini menggunakan metode survei karena metode ini dapat memberikan gambaran kepada peneliti tentang bagaimana seseorang berpikir dan berlaku sesuai dengan pernyataan pada kuesioner (Neuman, 2011). Metode penelitian yang akan digunakan penulis untuk penelitian ini adalah metode penelitian kuantitatif eksplanatori.

\section{Partisipan}

Partisipan merupakan Warga Negara Indonesia yang menjadi atlet dan terdaftar di induk organisasi olahraga Indonesia serta pernah mengalami cedera berat, pengambilan data dilakukan dengan metode survei dan mendapatkan 72 responden dengan responden laki-laki sebanyak 40 dan responden perempuan sebanyak 32 orang

Pemilihan partisipan dalam penelitian ini menggunakan non probability sampling, teknik ini digunakan jika tidak memiliki data atau pengetahuan tentang seberapa besar populasi yang harus diteliti. Peneliti menggunakan teknik dari Pallant (2020) karena tidak mengetahui atau memiliki data populasi yang harus diteliti dan dipilih karena menghadapi keterbatasan dana dan waktu penelitian.

\section{Pengukuran}

\section{Skala Self-Determination}

Penelitian ini penulis menggunakan skala self-detremination yang disusun oleh penulis berdasarkan teori self-determination dari Deci dan Ryan (2012) yang terdiri dari 26 aitem. Skala ini melakukan pengukuran terhadap 3 aspek dari self-determination yaitu Autonomy, Relatedness, dan Competence. Dalam penelitian ini peneliti menggunakan model skala likert yang terdapat angka 1 sampai 4 (sangat tidak setuju, tidak setuju, setuju, sangat setuju) dengan koefisien reliabilitas yang cukup baik $(\alpha=.816)$.

\section{Skala Grit}

Pengukuran grit yang digunakan dalam penelitian ini merupakan Grit Scale yang adopsi dari Duckworth dkk. (2007) yang terdiri dari 12 aitem yang telah diterjemahkan ke dalam Bahasa Indonesia. Skala ini melakukan pengukuran terhadap 2 dimensi dari grit yaitu: Consistency of Interest dan Perseverance of Effort. Dalam penelitian ini peneliti menggunakan model skala likert yang terdapat angka 1 sampai 4 
(sangat tidak setuju, tidak setuju, setuju, sangat setuju) yang dirasa sudah memenuhi kriteria kebutuhan penelitian ini, alat ukur asli dari penelitian ini memiliki reabilitas cronbach alpha sebesar $(\alpha=.831)$

Analisis Data

Dalam penelitian ini memiliki tujuan untuk menguji pengaruh antar dua variabel, yakni grit dengan selfdetermination dengan menggunakan teknik korelasi pada IBM SPSS Statistic 25.0 version for Windows. peneliti sebelumnya melakukan uji asumsi terlebih dahulu, yang mana uji asumsi tersebut adalah uji normalitas, uji linearitas, uji outlier, uji homokedastisitas. Untuk menguji hipotesis penelitian, penulis menyebar kuesioner dan mendapatkan 72 partisipan dengan variabel self-determination memiliki ratarata 85.67 dengan standar deviasi sebesar 5.462. Nilai minimal dari data self-determination sebesar 73 sedangkan maksimalnya memiliki 99. Variabel grit memiliki rata-rata sebesar 36.06 dengan standar deviasi 4.630. nilai minimal dari data grit sebesar 25 sedangkan nilai maksimalnnya sebesar 46.

\section{HAS I L P E N ELIT I A N}

Partisipan merupakan Warga Indonesia yang menjadi atlet dan terdaftar di induk organisasi olahraga Indonesia serta pernah mengalami cedera berat, pengambilan data dilakukan dengan metode survei dan mendapatkan 72 responden dengan responden laki-laki sebanyak 40 dan responden perempuan sebanyak 32 orang

Untuk menguji tingkat grit dengan self-determination dilakukan uji regresi dengan hasil nilai R2 sebesar 0.197 atau sebesar 19,7\%. Hal ini menunjukan self-determination dapat dijelaskan sebesar 19,7\% oleh variabel independen grit sedangkan 80,3\% lainnya dipengaruhi oleh variabel lain. Dengan nilai signifikantsi sebesar 0,00 di mana pengaruh grit dan self-determination berpengaruh secara signifikan.

\section{I S K US I}

Berdasarkan hasil analisis regresi sederhana yang dilakukan oleh peneliti dapat diketahui bahwa grit mempengaruhi self-determination secara signifikan, dengan hasil dari R square menunjukan bahwa terdapat pengaruh sebesar 19,7\% antara variabel grit terhadap self-determination. Hal ini menunjukan bahwa hipotesis penelitian diterima sedangkan hipotesis nihil ditolak dimana terdapat pengaruh yang signifikan pada grit terhadap self-determination. Hal ini dikarenakan individu dengan grit yang tinggi mampu mengatasi kegagalan atau kemunduran yang akan menghambat mereka untuk mencapai tujuannya. Sejalan dengan pernyataan Duckworth, dkk. (2007) di mana dalam penelitiannya mengatakan bahwa individu dengan grit yang tinggi akan memanfaatkan kemampuan yang mereka miliki dengan lebih baik karena mereka rela mengeluarkan usaha yang lebih besar, tidak mudah terganggu oleh proyek lain, dan mampu mengabaikan hal-hal yang kurang relevan dengan tujuan, serta tidak mudah berkecil hati saat mengalami kegagalan atau kemunduran dalam proses mengejar tujuannya.

Informasi dalam penelitian ini menyebutkan bahwa terdapat pengaruh yang signifikan pada grit terhadap self-determination atlet yang memutuskan kembali pasca mengalami cedera berat, hal ini dikarenakan orang dengan grit yang tinggi akan menunjukan sebuah sifat yang konsisten akan sesuatu yang disukainya dalam konteks penelitian ini adalah cabang olahraga yang dipilih oleh atlet, di mana cedera yang dialami oleh individu meskipun berkemungkinan adanya dampak besar pada penurunan performa dari sebelum cedera. Namun, hal tersebut tidak membuat individu yang mempunyai grit yang tinggi berhenti untuk melakukan hal yang konsisten yaitu berkompetisi pada cabang olahraga yang dipilihnya. Hal ini didukung dengan pernyataan bahwa secara keseluruhan, penelitian tentang grit telah 
menunjukkan bahwa individu dengan grit yang lebih tinggi berkemungkinan lebih besar untuk memperoleh tingkat pendidikan yang lebih tinggi, memiliki IPK yang lebih tinggi, lebih optimis (Duckworth dkk., 2007), berkomitmen untuk lebih banyak melakukan latihan secara mandiri dan memiliki tingkat keterlibatan dalam olahraga yang lebih tinggi daripada individu yang memiliki grit rendah (Martin dkk., 2015).

Dalam penelitian Podlog \& Eklund (2010) self-determination merupakan salah satu faktor yang dapat membuat atlet kembali berkompetisi setelah mengalami cedera berat. Hasil dari penelitian yang dilakukannya menunjukan bahwa atlet yang mempunyai self-determination yang tinggi akan mempengaruhi keinginannya untuk kembali berkompetisi, serta membantu atlet tersebut untuk lebih positif dalam menjalani masa rehabilitasi saat cedera. Penelitian yang meneliti bagimana pengaruh grit terhadap self-determination dalam konteks atlet yang kembali pasca mengalami cedera berat masih sangat sedikit. Sehingga penelitian ini dapat menjadi acuan untuk penelitian selanjutnya apabila ingin meneliti grit dan self-determination lebih jauh lagi atau meneliti dalam konteks yang berbeda. Serta dalam penelitian ini mayoritas responden peneltian masih cenderung menggunakan persepsi untuk menentukan apakah dia mengalami cedera berat, maka hendaknya dalam penelitian selanjutnya agar menyertakan rekam medis agar penelitian lebih akurat.

Selama penulis melakukan penelitian, terdapat hambatan yang dialami oleh penulis antara lain, penulis kesulitan dalam proses mencari refrensi untuk membantu jalannya penelitian karena penelitian tentang grit dalam konteks atlet memang sudah banyak namun yang secara spesifik membahas tentang kembalinya atlet pasca cedera berat masih sangat sedikit. Kemudian, untuk indikator keparahan cedera atlet sangat bergantung pada persepsi karena adanya keterbatasan, yaitu tidak adanya rekam medis.

\section{S I M P U L A N}

Berdasarkan hasil analisis regresi sederhana yang dilakukan oleh peneliti dapat diketahui bahwa grit mempengaruhi self-determination secara signifikan, dengan hasil dari R square menunjukan bahwa terdapat pengaruh sebesar $19,7 \%$ antara variabel grit terhadap self-determination.

\section{U C A P A N T ER I MAKASIH}

Terima kasih kepada seluruh partisipan yang telah bersedia atas berkontribusinya terhadap penelitian ini, terima kasih pula kepada Fakultas Psikologi Universitas Airlangga yang telah memfasilitasi penelitian ini, semoga manfaat penelitian ini bisa dirasakan secara luas khususnya pada bidang Psikologi

\section{DEKLARASI POTENSI TERJADINYA KONFLIK KEPENTINGAN}

Azzah Ambarani Hidayat dan Afif Kurniawan, M.Psi., Psikolog. tidak bekerja, menjadi konsultan, memiliki saham, atau menerima dana dari perusahaan atau organisasi manapun yang mungkin akan mengambil untung dari diterbitkannya naskah ini. 


\section{PUSTAKA ACUAN}

Bianco, T., \& Eklund, R. C. (2001). Conceptual considerations for social support research in sport and exercise settings: The case of sport injury. Journal of sport and exercise psychology, 23(2), 85107.

Brown, G. T., Hainline, B., Kroshus, E., \& Wilfert, M. (2014). Mind, body and sport: Understanding and supporting student-athlete mental wellness. Indianapolis, IN: National Collegiate Athletic Association.

Deci, E. L., \& Ryan, R. M. (2012). Motivation, personality, and development within embedded social contexts: An overview of self-determination theory. In The Oxford handbook of human motivation (pp. 85-107). Oxford University Press.

Duckworth, A. (2016). Grit: Kekuatan Passion dan Kegigihan (Revisi). PT. Gramedia Pustaka Utama.

Duckworth, A., \& Gross, J. J. (2014). Self-Control and Grit: Related but Separable Determinants of Success. Current Directions in Psychological Science, 23(5), 319-325. https://doi.org/10.1177/0963721414541462

Duckworth, A. L., Peterson, C., Matthews, M. D., \& Kelly, D. R. (2007). Grit: Perseverance and Passion for Long-Term Goals. Journal of Personality and Social Psychology, 92(6), 1087-1101. https://doi.org/10.1037/0022-3514.92.6.1087

Foss, K. D. B., Thomas, S., Khoury, J. C., Myer, G. D., \& Hewett, T. E. (2018). A school-based neuromuscular training program and sport-related injury incidence: A prospective randomized controlled clinical trial. Journal of Athletic Training, 53(1), 20-28. https://doi.org/10.4085/1062-6050173-16

Gledhill, A., \& Forsdyke, D. (2021). The psychology of sports injury: From risk to retirement. Routledge.

Hasanah. (2019). HUBUNGAN PERSEN LEMAK TUBUH DAN TINGKAT KECUKUPAN ASUPAN ZAT GIZI MAKRO DENGAN KONDISI FISIK ATLET FUTSAL DI SURABAYA. Perpustakaan Universitas Airlangga, 1, 1-8.

Hughes, R., \& Coakley, J. (2016). Positive Deviance among Athletes: The Implications of Overconformity to the Sport Ethic. Sociology of Sport Journal, 8(4), 307-325. https://doi.org/10.1123/ssj.8.4.307

Johnston, L. H., \& Carroll, D. (1998). The context of emotional responses to athletic injury: A qualitative analysis. Journal of Sport Rehabilitation, 7(3), 206-220. https://doi.org/10.1123/jsr.7.3.206

Lavallee, D., Kremer, J., \& Moran, A. (2020). Psychology of Sport. Social Sciences in Sport, 169-189. https://doi.org/10.5040/9781492595885.ch-003

Magee, D. J., Zachazewski, J. E., Quillen, W. S., \& Manske, R. C. (2010). Athletic and Sport Issues in Musculoskeletal Rehabilitation-E-Book. Elsevier Health Sciences. 
Martin, J. J., Byrd, B., Watts, M. L., \& Dent, M. (2015). Gritty, hardy, and resilient: Predictors of sport engagement and life satisfaction in wheelchair basketball players. Journal of Clinical Sport Psychology, 9(4), 345-359. https://doi.org/10.1123/jcsp.2015-0015

Neuman, W. L. (2011). Social Research Methods: Qualitative and Quantitative Approaches. In Pearson Education.

O’Connell, S., \& Manschreck, T. C. (2012). Playing through the pain : Current Psychiatry.

Pallant, J. (2020). SPSS survival manual: A step by step guide to data analysis using IBM SPSS. Routledge.

Podlog, L., \& Eklund, R. C. (2007). The psychosocial aspects of a return to sport following serious injury: A review of the literature from a self-determination perspective. Psychology of Sport and Exercise, 8(4), 535-566. https://doi.org/10.1016/j.psychsport.2006.07.008

Podlog, L., \& Eklund, R. C. (2010). Returning to competition after a serious injury: The role of selfdetermination. Journal of Sports Sciences, 28(8), 819-831. https://doi.org/10.1080/02640411003792729

Ristolainen, L., Kettunen, J. A., Kujala, U. M., \& Heinonen, A. (2012). Sport injuries as the main cause of sport career termination among Finnish top-level athletes. European Journal of Sport Science, 12(3), 274-282. https://doi.org/10.1080/17461391.2011.566365

Santi, G., \& Pietrantoni, L. (2013). Psychology of sport injury rehabilitation: A review of models and interventions. Journal of Human Sport and Exercise, 8(4), 1029-1044. https://doi.org/10.4100/jhse.2013.84.13

Santi, G., Pietrantoni, L., O’Connell, S., Manschreck, T. C., Ristolainen, L., Kettunen, J. A., Kujala, U. M., Heinonen, A., Wilson, G., Pritchard, M., Pa, Mellalieu, S. D., Hanton, S., Podlog, L. ;, Eklund, R., Klenk, C. a, Ryan, R. M., Deci, E. L., Scharneck, L., ... Brown, G. T. (2013). Sport injury and illness: Elite skiers describe their experiences. Jurnal Olahraga Prestasi, 8(3), 1087-1101. https://doi.org/10.1080/02701367.1999.10608033

Scharneck, L. (2017). The mediating effect of self-determined motivation in student-athlete perceptions of coaching behaviors and its effect on grit and mental toughness. 1-50.

Van Raalte, J. L., Brewer, D. D., Brewer, B. W., \& Linder, D. E. (1993). Sport psychologists' perceptions of sport and mental health practitioners. Journal of Applied Sport Psychology, 5(2), 222-233. https://doi.org/10.1080/10413209308411316

Williams, J. M., \& Roepke, N. (1993). Psychology of injury and injury rehabilitation. Handbook of Research on Sport Psychology, 815-839. 